\title{
A INFLUÊNCIA DA MÍDIA NO TRIBUNAL DO JÚRI
}

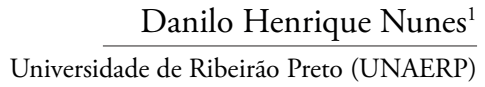 \\ Rafael Catani Lima² \\ Centro Universitário FAFIBE. \\ Jonatas dos Santos Silva ${ }^{3}$ \\ Centro Universitário da Fundação Educacional de Barretos/SP
}

Artigo recebido em: 27/01/2019

Artigo aceito em: 27/05/2019

\section{Resumo}

O tribunal do júri é o único instituto judicial previsto na Constituição Federal que conta com participação popular, não sendo possível negar seu papel relevante para a sociedade, já que visa, pelo menos em tese, inclusive, evitar o arbítrio estatal. Porém, em razão dos anseios midiáticos, torna-se um instituto devassado. Deste modo, o presente artigo tem como objetivo analisar a influência midiática exercida no tribunal do júri e sua relação com a presunção de inocência, a qual, muitas vezes, é afetada pelo uso demasiado das fontes de informação. Com a análise de diversos autores, o estudo trata de ressaltar o sensacionalismo como forma de atrair para os meios de comunicação a atenção da população, entre eles, os jurados. Esta pesquisa guiou-se pelo método dedutivo, buscando contemplar as arbitrariedades impostas aos suspeitos, principalmente nos crimes dolosos contra a vida, e que são encontradas em livros, artigos científicos, publicaçóes de grandes meios de comunicação, resultando na ponderação dos princípios da liberdade de informação e da presunção de inocência do acusado, buscando assegurar ao acusado a dignidade humana e, provisoriamente, o uso de do instituto do desaforamento, bem como a renúncia do respectivo tribunal do júri pelo próprio acusado.

Palavras-chave: influência da mídia; tribunal do júri; decisôes dos jurados.

1 Mestre em Direitos Coletivos e Cidadania pela Universidade de Ribeirăo Preto - Unaerp - Ribeirão Preto/SP. E-mail: dhnunes@hotmail.com

2 Doutorando em Direito pela PUC/SP. Mestre em Direitos Coletivos e Cidadania. Professor e Coordenador do Curso de Direito e de Pós-Graduação em Direito do Centro Universitário Fafibe em Bebedouro/SP. Advogado. E-mail: rafael.catani.adv@gmail.com

3 Graduado pelo Centro Universitário da Fundação Educacional de Barretos/SP. E-mail: jonatashet23@gmail.com 


\section{THE INFLUENCE OF THE MEDIA IN THE COURT OF JUSTICE}

\section{Abstract}

The Jury's Courtistheonlyjudicialinstitute foreseen in the Federal Constitution that has popular participation, and it cannot be denied its relevant role for society, since it aims at least in theory to avoid state arbitration. But due to media anxieties, it becomes a destitute institute. Thus, this article aims to analyze the media influence exercised in the Court of the Jury and its relation to the presumption of innocence, which is often affected by the overuse of information sources. With the analysis of several authors, the study tries to emphasize sensationalism as a means of attracting the attention of the population, among them jurors, to the media. Their research was guided by the deductive method, seeking to contemplate the arbitrariness imposed on the suspects, especially in crimes against life, which are found in books, scientific articles, publications of major media, resulting in the pondering of the principles of freedom of information and of the presumption of innocence of the accused, seeking to ensure to the accused the human dignity and provisionally the use of the instigation institute, as well as the resignation of the respective Court of the jury by the accused himself.

Keywords: influence of the media; jury court; decisions of the jury.

\section{Introdução}

A mídia tem um poder imenso, tendo aqueles que asseveram que ela é o quarto poder, ao lado dos poderes Executivo, Legislativo e Judiciário, contando com proteção ressalvada pela Constituição Federal, em rol de garantias fundamentais da pessoa humana, sendo, desse modo, clausula pétrea.

Por ser um órgão composto por variados tipos de pessoas, o tribunal do júri é mais propício ao sensacionalismo da mídia, resultando em debates em locais públicos e que refletem em plenário de julgamento, muitas das vezes, condenando o acusado antes mesmo que este exerça sua defesa, já que figura como um "inimigo" da sociedade, o qual, da maneira o mais prolongada possível, deve permanecer enclausurado.

As políticas criminais, ao lado da influência midiática, ao transformar o suspeito de determinado crime em inimigo, atribuem à sociedade a sensação de dever de castigar aquele que está sendo julgado, mesmo que este não mereça receber qualquer tipo de punição, pois pode ser o caso de o acusado ser inocente. Isto 
porque cada vez mais os delitos contra a vida são o embasamento central dos noticiários, os quais são mais presentes em quase todos os lares brasileiros, seja por meio da internet ou da televisão.

Desse modo, este artigo estuda a influência que os meios de comunicação exercem sobre os jurados e suas consequências ao extrapolar os poderes constitucionais concedidos, ignorando o dever de apenas informar os casos e emitindo juízos de valor, como se tem visto. Cumpre ressaltar que a influência afeta até a presunção de inocência dos acusados, produzindo em larga escala a cultura do medo, quando cada crime ocorre, com único objetivo de auferir lucro e captar audiência.

A partir desse contexto, e visando à dignidade humana daquele que está sendo submetido a julgamento, surge o fim de buscar a ponderação dos abusos comunicativos, não os suprimindo, visto que este estudo não tem como ideia o cerceamento do princípio da liberdade de expressão, e sim sua ponderação quando conflitante com outra garantia constitucional. O direito de ser julgado por seus semelhantes é visto com bons olhos se exercido de forma correta, proporcionando ao réu o devido processo legal. Cria-se a expectativa de que o tribunal do júri possa unicamente garantir a participação da população no poder judiciário, evitando-se quaisquer abusos autoritários, mantendo-se a coerência e a busca da efetiva verdade, caso esteja livre das pressōes exercidas diariamente pelos noticiários.

\section{Origem do tribunal do júri}

O tribunal do júri é um órgão especial do Poder Judiciário de primeira instância, colegiado e heterogêneo, consistente em 1 juiz togado (presidente) e 25 cidadãos por sessáo de julgamento, dos quais 7 serão escolhidos como jurados a partir de sorteio e que julgam os crimes dolosos contra a vida, conforme o art. 447 do Código de Processo Penal (CPP) (BRASIL, 1941).

Cabe apontar que prezado instituto é um órgão temporário, em virtude de ser constituído em sessóes periódicas no ano, com soberania em relação às suas respectivas decisóes, tomadas de maneira sigilosa e com íntima convicção, não necessitando ser fundamentada pelos seus integrantes (jurados), como prelecionam o art. 453 do mesmo diploma legal supracitado e o art. 5º, inc. XXXVIII, da Constituição Federal (CF) (BRASIL, 1941; 2018).

Trata-se de um direito fundamental estabelecido na Lei Magna vigente, com a participação de cidadãos na aplicação da justiça criminal nos crimes dolosos contra a vida, tornando-se umas das mais democráticas instituiçóes, pois visa combater os arbítrios estatais. 
Quanto a suas origens, ainda que tenha recebido os primeiros traços e aspectos de sua forma no solo britânico (BARBOSA, 1897), a origem do júri encontra-se de forma variada nas opinióes dos autores no que tange às suas origens mais remotas. O máximo que se pode afirmar é que: tribunais populares sempre existiram, tendo o júri que conhecemos atualmente surgido no mundo anglo-saxão (FREITAS, 2016).

Cumpre anotar que a antiguidade greco-romana também conviveu com ilustrado tribunal, constituindo as primeiras bases do júri atual, mas nada comparado à inserção que o modelo britânico proporcionou. Em solo brasileiro, o júri surgiu apenas no século XIX, com a promulgaçáo do Decreto Imperial de 18 de junho de 1822, assinado pelo Príncipe Regente Dom Pedro I, antes mesmo da independência, com competência restrita aos delitos e abusos da imprensa (MARQUES, 1963 apud FREITAS, 2016, p. 15), definidos como toda publicação, ainda que verbal, que fosse contra a ordem e a tranquilidade da União, além das doutrinas incendiárias e subversivas, capazes de promover a anarquia e destruir o sistema do Reino.

A Constituição Federal de 1824 foi a primeira a tratar sobre o tribunal do júri, em seu art. 152, integrado ao Poder Judiciário, alcançando, assim, apenas status Constitucional. De igual modo, a Constituição de 1934 deixou o respectivo mecanismo fora do rol dos direitos e garantias fundamentais. As Constituiçôes de 1891, de 1946, de 1967 e a derradeira Constituição de 1988, "é que deram menção ao Júri na enumeração dos direitos e garantias individuais" (PORTO, 2007, p. 26).

O júri na sociedade brasileira contemporânea tem previsão na Carta Magna, no art. $5^{\circ}$, inc. XXXVIII. Já a lei que prevê sua organização é infraconstitucional, estando mais precisamente nos arts. 406 a 490 do Código de Processo Penal, de outubro de 1941, com as alteraçóes introduzidas pela Lei n. 11.689, de 2008.

Ainda que seja um preceito constitucional, os requisitos para ocupar cargo de jurado não são definidos pelo mesmo diploma, tampouco pelo Código de Processo Penal, o que enseja vários questionamentos e, infelizmente, seu mau uso, o que compromete a Justiça, bem como os preceitos legais e constitucionais, que serão abordados no presente trabalho.

\section{Princípios constitucionais e processuais do júri}

Como visto, a Constituição Federal de 1988 recepcionou a instituição do júri, fazendo previsão, em seu art. $5^{\circ}$, inc. XXXVIII, aos princípios expostos a seguir. 


\subsection{Plenitude de defesa e sigilo das votaçóes}

No júri, é necessário mais que a ampla defesa, que é cabível em todos os tipos de processos, pois, em tal situação, a atuação da defesa deve ser plena, devendo ser o trabalho do defensor o mais perfeito possível. O juiz e o promotor deveráo ser vigilantes quanto ao desempenho do advogado, podendo ambos requerer (promotor) ou determinar (juiz) a dissoluçáo do conselho de sentença, por considerar o acusado totalmente indefeso.

Renato Brasileiro de Lima menciona a diferença entre plenitude de defesa e ampla defesa, ressaltando que o advogado de defesa náo precisa se restringir a uma atuação exclusivamente técnica, ou seja, é perfeitamente possível que o defensor utilize a argumentação extrajurídica, valendo-se de razôes de ordem social, emocional etc. (LIMA, 2017).

É possível concluir que o referido princípio visa proteger o acusado, para que este, se inocente ou não tão culpável, seja condenado pela insuficiência de seu defensor.

Quanto ao sigilo das votaçóes, os jurados, ao votar, decidem de forma secreta, não sendo possível identificar como cada um estabeleceu seu voto. $\mathrm{O}$ citado princípio busca manter a segurança e a tranquilidade dos jurados, sem medo de possíveis represálias. A votação é feita em sala especial, como faz disposição o art. 485, caput, do Código de Processo Penal, não violando de forma alguma o princípio da publicidade. Tal disposição já se encontra pacificada na jurisprudência em razão da previsão legal do art. $5^{\circ}$, inc. LX, da Lei Magna, que dispóe sobre a restrição de publicidade de atos processuais quando o interesse social exigir.

\subsection{Soberania dos veredictos e competência para o julgamento dos crimes dolosos}

Prelecionado princípio traduz que um tribunal formado por juízes de Direito não pode modificar a decisão de um corpo de jurados no que diz respeito ao mérito de suas decisóes. Contudo, tal afirmação não demonstra que as decisóes dos jurados são irrecorríveis, podendo ser revisada por Tribunal competente para isso. Para tanto, é necessário diferenciar duas situaçóes, conforme a disposição dada pelo art. 593, inciso III e seguintes do Código de Processo Penal (CPP) (BRASIL, 1941):

(i) Impugnaçấo à decisão dos jurados propriamente em si, ou seja, aquela proferida por conselho de sentença. Nestes casos, 
caso haja recurso de apelação, o Tribunal de Justiça não tem competência para alteração. $\mathrm{O}$ que se pode fazer é anulação a decisão dos jurados e determinar a realização de novo júri.

(ii) Impugnação à decisão do Juiz-Presidente. Neste caso, em caso de recurso de apelação, poderá o Tribunal de Justiça modificar a decisão imposta.

No tocante à competência do tribunal do júri, determinam o art. $5^{\circ}$, inc. XXXVIII, alínea $d$, da Constituiçáo Federal c. com o art. $74, \$ 1^{\circ}$, do Código de Processo Penal, que compete ao tribunal do júri a competência para o julgamento dos crimes dolosos contra a vida, sejam eles na forma tentada ou consumada. Complementando o dispositivo anterior, os arts. 76, 77 e 78, inc. I, do Código de Processo Penal doutrinam a aplicação do tribunal do júri nos crimes conexos aos dolosos contra a vida.

\section{A mídia e sua influência nas decisóes dos jurados}

Nilo Batista (2003 apud FREITAS, 2016, p. 142) aponta que a vinculaçáo entre a mídia e o sistema penal é algo que sempre existiu ao longo de toda história, o que se denomina criminologia midiática (ZAFFARONI, 2012).

Já Pierre Bordieu (1997, p. 23) reconhece que a influência da mídia nos dias atuais "exerce uma espécie de monopólio sobre a formação das cabeças de uma parcela muito importante da populaçáo", principalmente no que se refere ao âmbito penal, demonstrando que os meios de comunicaçáo, mesmo quando desprovidos de qualquer natureza, já demonstravam interesse no sistema criminal, fomentando, assim, a criação de estereótipo do criminoso e a cultura do medo.

A mídia dominou de forma predominante a questão criminal, tendo em vista que a violência faz parte da vida cotidiana, migrando de um jornalismo limitado, que, de forma coesa e sucinta, informava os fatos ocorridos, para atuar como verdadeira máquina estatal, visando apenas à instigação, o que se reflete diretamente nos tribunais do júri, deixando de ser imparcial e tomando parte no debate, expondo apenas seus pontos de vista e posiçôes (ALMEIDA; GOMES, 2013 apud FREITAS, 2016, p. 181).

É sabido que "Crimes dolosos contra a vida, via de regra, têm atraído o sensacionalismo da mídia [...]" (PRATES; TAVARES, 2008, p. 34), que são de competência do tribunal do júri. Os juízes leigos, ao decidirem apenas por íntima convicção, favorecem os meios midiáticos, pois não é possível identificar qual jurado fora influenciado pelo sensacionalismo e deixou de observar a imparcialidade, tendo em vista o sigilo das votaçôes. 
A falta da imparcialidade pelos jurados está diretamente atrelada à liberdade de outrem, que está sendo discutida. Resta ressaltar que os jurados julgam segundo suas convicçóes, tomadas pelas provas produzidas em plenário, decidindo de maneira justa e buscando alcançar a justiça em sua plenitude. Para Capez (2009, p. 630), a imparcialidade busca a garantia individual dos acusados:

A finalidade do tribunal do júri é a de ampliar o direito de defesa dos réus, funcionando como uma garantia individual dos acusados pela prática de crimes dolosos contra a vida, e permitir que, em lugar do juiz togado, atado a regras jurídicas, sejam julgados pelos seus pares.

Surge, assim, a difícil tarefa de reservar ao acusado um julgamento justo, pois maléfica é a atuação da imprensa na divulgação dos casos em que há grande uso de violência, a qual, via de regra, é utilizada nos crimes dolosos contra vida, sendo estes, geralmente, os que atraem o interesse da população.

\subsection{Liberdade de imprensa}

Preceituam Mendes e Branco (2016) que a liberdade de expressão é um dos direitos fundamentais mais preciosos, sendo reivindicada pelo ser humano em toda a história. Se não fosse assim, a Constituição Federal Brasileira de 1988 não reservaria vários dispositivos acerca do tema, surgindo como direito assegurado à sociedade e, principalmente, aos meios de comunicação, que entregam aos primeiros informaçóes e fatos, que devem ser descritos e mencionados de forma imparcial.

É sabido que a liberdade de imprensa não pode sofrer censuras pelo poder estatal. Contudo, tal elemento não é absoluto, haja vista que pode sofrer restriçôes, conforme disposição do art. $220, \$ 1^{\circ}$, da Constituição Federal.

Complementa Cruz (2003 apud LEITE, 2011, p. 9): “É que o disposto no artigo 220 está intimamente relacionado, também, à dignidade da pessoa humana. A constituiçấo não permite um total sacrifício do particular ao interesse social. A relaçáo tem um limite, que é a dignidade da pessoa humana”.

O respeito à dignidade humana é erigido à condição de limite da liberdade de expressão, pois o primeiro é a base do Estado democrático e vetor hermenêutico indispensável para a compreensão adequada de qualquer direito. Neste viés, a liberdade de imprensa deve ser utilizada apenas como forma de transmissão de informaçóes e de notícias ocorridas nos cenários regional, nacional e mundial, cumprindo, assim, sua finalidade, sem que houvesse prejuízo ao indivíduo e à sua dignidade. Mello (2010, p. 119), neste sentido, pontua que: 
Sabe-se que não é permitido aos meios de comunicação, se utilizar da prerrogativa da liberdade de informação jornalística, que lhe é garantida pela Constituição Federal, para divulgar notícias que ofendam a outras liberdades igualmente garantidas, tais como a intimidade, a vida privada e a presunção de inocência.

A ideia de insegurança, acusaçôes a determinadas pessoas e pregação da cultura do medo trazem como consequência o isolamento de pessoas, que acarreta diretamente no tribunal do júri, já que os jurados representam aquela parcela de pessoas que se sentem ameaçadas, excluindo-se tacitamente o ideal de que o acusado fosse julgado por um semelhante a si e afastando, desse modo, a aplicaçáo do princípio da presunção de inocência.

Deve-se, assim, buscar o interesse público, e não o privado, já que o último tem como único intuito o interesse de auferir lucro sobre os processos criminais, mesmo que, para tal, tenha de deixar de observar sua respectiva finalidade.

\subsection{Da presunção de inocência}

A Constituição Federal preceitua, em seu art. 5º, LVII, que ninguém será considerado culpado até o trânsito em julgado de sentença penal condenatória, demonstrando, assim, a presunção da inocência ou da não culpabilidade.

O respectivo princípio deve ser aplicado no tribunal do júri, haja vista que o denunciado, ao ser julgado pelos seus semelhantes, deverá ter observado o estado presumível de inocência garantida até que se prove o contrário, ainda que tenha sido "condenado" pela mídia e pela opinião pública.

Garantindo a presunçáo de inocência do réu, observará a dignidade da pessoa humana, e, nos termos de Sarlet (2012, p. 131), “[...] o Estado deverá ter como meta permanente, a proteção, promoção e realização de uma vida com dignidade para todos [...]", impedindo que o réu seja alvo de humilhaçóes, e o uso da força midiática de forma totalitária, pois em ambas situaçôes servem aos ensejos dos meios de comunicação, que pregam a intolerância e a condenação dos suspeitos a qualquer custo.

Contudo, no Brasil, não há a observância desses preceitos constitucionais, bem como raros são os casos de tribunais que atuam com veredictos pré-moldados, seja pela cultura do medo implementada em nossa sociedade ou pela vigorosa opinião pública sobre determinado caso concreto. 


\subsection{Liberdade de imprensa e presunção de inocência do acusado}

Conforme o desenvolver do estudo, verificou-se que os princípios da presunção de inocência do acusado e a liberdade de imprensa colidem, sendo que ambos são direitos ou garantias fundamentais relacionadas a liberdade, fixando de forma veemente os limites do poder estatal.

A utilização da liberdade de imprensa de forma arbitraria e sensacionalista, ou seja, de modo a interferir na composição da opinião pública e na construção de valores sociais e individuais, atinge diretamente o princípio da presunçáo de inocência do acusado. Neste aspecto, Garland (2008) relata que a mídia pós-moderna funciona como elemento oportunista, tomando os objetos do crime como objeto central de seus noticiários, já que estáo inseridos em uma sociedade que cada vez mais vivencia o fenômeno criminal. Mediante a presente inserçáo apresentada, é possível verificar que programas inteiros são criados com matérias criminais, tornando-se um atrativo imperdível, já que muitas das vezes ocupam os horários de pico de audiência.

Importante ponderar que é sabido que, no ordenamento jurídico, os direitos em conflito não podem ser hierarquizados, sendo que o caso concreto dirá qual deles devem recuar, estabelecendo-se, assim, uma ponderação aceitável. Para isso, a utilização do princípio da proporcionalidade é a ferramenta essencial para resolver as possíveis diligências. Para definir proporcionalidade, ater-se-á à menção feita por Schäfer e DeCarli (2007 apud LEITE, 2011, p. 19):

O princípio da proporcionalidade permite que o magistrado; diante da colisão de direitos fundamentais, decida de modo que se maximize a proteção constitucional, impedindo o excesso na atividade restritiva aos direitos fundamentais. $\mathrm{O}$ objetivo não é anular um ou outro princípio constitucional, mas encontrar a solução que mantenha os respectivos núcleos essenciais.

Sendo analisado o caso concreto e verificada a dificuldade em estabelecer a proporcionalidade, é preferível que a liberdade de imprensa delimite sua atuaçáo até o necessário, rejeitando a parte supérflua na presente situaçáo, pois não é razoável que a liberdade de imprensa não essencial prevaleça em detrimento da presunção de inocência em seu grau necessário, em virtude de estar mais atrelada à liberdade do indivíduo, limitando-se, porém, para que não ocorram sacrifícios desnecessários de um em relação ao outro. 
Importante observar que a presunção de inocência deve ser sempre garantida ao indivíduo, sob os ditames da própria Justiça. Por outro lado, é necessário ressaltar que é livre o fornecimento de informações à populaçáo, desde que se limitem às previsóes legais e verídicas, não induzindo a erro seu público-alvo.

\section{Análise de casos concretos}

Como dito anteriormente, fica a encargo dos jurados o árduo trabalho de julgar sem se submeter à influência midiática. Nota-se, porém, que, em detrimento da própria dificuldade, o plenário do júri julga conforme suas emoçôes, que são aguçadas com o conteúdo dos noticiários, como se verá nos exemplos expostos a seguir.

\subsection{Caso Daniella Perez}

A atriz Daniella Ferrante Perez Gazolla, filha da novelista Glória Perez, foi morta em 1992 com 18 golpes de tesoura, na cidade do Rio de Janeiro. O ator Guilherme de Pádua, que atuava com a vítima na novela De Corpo e Alma, e sua esposa Paula Thomaz, foram denunciados como autores do delito.

Em virtude de a vítima ser jovem e atuar na maior emissora do país, a TV Globo, que de igual maneira empregava o então acusado do delito, causou-se grande mobilização midiática, e Freitas (2016) pondera que, até então, não havia crime anterior que tivesse mobilizado a mídia, atraindo a atençấo diária de uma população inteira.

A veiculação em vários programas de televisão, rádios e capas de revista foi de tamanha proporção que se tornou impossível calcular sua abrangência. Freitas novamente de modo objetivo - demonstra a influência de um programa de grande repercussão para o fato:

O programa JORNAL NACIONAL, exibido pela Rede Globo de Televisão na data de 29.12.1992, dá uma mostra razoável de como a televisão cuidou do crime em exame. $\mathrm{O}$ referido Jornal televisionado exibiu uma reconstituição não oficial do crime, a qual participaram atores muitos parecidos com a vítima e os acusados. [...]. Sem praticamente nenhum tipo de ressalva, o repórter [...], fez afirmaçôes categóricas, como se não existisse nenhuma dúvida sobre quem seria o assassino da atriz Daniella Perez. Inclusive o nome do principal suspeito até entâo foi pronunciado e repetido incontáveis vezes [...] (FREITAS, 2016, p. 214). 
Neste sentido, o complementa com a respectiva reportagem televisiva apontada:

[...] em seguida os dois saem, cada um no próprio carro. Guilherme segue Daniella Perez por dez quilômetros. Meia hora depois, eles entram numa rua pouco movimentada. Daniella vai para o carro de Guilherme e eles começam a brigar. Ele tenta estrangular a atriz, ela foge. Guilherme pega uma tesoura no porta-luvas e persegue Daniella. A atriz é assassinada com quinze golpes de tesouro no peito e três no pescoço. Guilherme abandona o corpo no mato e foge. $\mathrm{O}$ carro do ator foi levado para Delegacia e examinado pelos policiais. Não havia marcas de sangue. O carro havia sido lavado poucas horas antes. Guilherme de Pádua foi preso em casa no começo da manhă. Ele tem vinte e três anos, é casado e a mulher está grávida de quatro meses. A polícia interrogou Guilherme por mais de três horas, ele estava descontrolado. No início Guilherme negou tudo, mas acabou confessando o crime (FREITAS, 2016, p. 214).

O promotor de justiça José Muiños Pińeiro, que atuou no caso, citou em entrevista o peso da mídia e a percepção dos jurados para o caso:

Era a primeira vez que não era necessário explicar para os jurados quem era a vítima, inclusive eu disse isso no júri. Daniella Perez estava todos os dias na novela das oito, era como se fosse a irmá ou a filha de todos os brasileiros - observa ele. - Eu trabalhava no interior e tinha chegado há dois anos na capital. Quando me vi diante de um caso de tanta repercussão, senti o peso. Eu estava o tempo todo exposto, vigiado pela mídia. E se eu não conseguisse condenar os assassinos? (ROCHA, 2012).

Guilherme e sua esposa, Paula, foram condenados a 19 anos de reclusão e a 18 anos e 6 meses de reclusão, respectivamente, tendo sido a pena da última reduzida a 15 anos pelo Tribunal de Justiça. Porém, antes que tivessem sido submetidos a plenário, é possível perceber que estes já eram considerados culpados, pois eram tratados de tal maneira.

\subsection{Caso Valíssia Fernandes de Jesus}

No dia 12 de outubro de 2016, por volta das 19 horas, na cidade de Pitangueiras (SP), regiāo de Ribeirão Preto, a acusada Mirian Aparecida Siqueira teria 
matado com uma faca a adolescente Valíssia Fernandes de Jesus, de 15 anos, que estava grávida de oito meses, com o intuito de ficar com o bebê, utilizando-se, para tanto, de meios ardis para atrair a vítima à sua residência para que ali pudesse cometer o delito.

No dia 14 de outubro, foi decretada a prisão temporária da ré Mirian e, posteriormente, sua prisão preventiva, tendo esta, logo em seguida, apresentado sua defesa prévia, alegando insanidade mental. Porém, após saneado o processo, foi determinada a realização de audiência de instrução e julgamento, tendo contado com a revolta dos familiares e amigos da vítima (TESTEMUNHA NEGA..., 2017).

O site de notícias G1, vinculado à Rede Globo, destacou em seus títulos expressóes que indicavam a autoria do delito e apontavam Miriam como a assassina, reproduzindo de forma prematura as suspeitas levantadas pela polícia, mesmo sem ter sido realizada qualquer diligência aprofundada sobre o caso:

\section{Mulher fingiu gestaçáo e matou jovem grávida para ficar com bebê, diz polícia \\ Delegado acredita que a suspeita tem gravidez psicológica e pla- nejou crime. Adolescente de 15 anos foi morta a facadas e teve filho retirado da barriga (OLIVEIRA; FIGUEIREDO, 2016).}

Após a publicação das manchetes e a inflamação em redes sociais, e antes mesmo de existir processo judicial contra os possíveis fatos praticados pela acusada, houve condenação pela população da pequena cidade, que de maneira constante demonstrou sua revolta.

Neste aspecto, é imprescindível o anexo de comentários tecidos no mesmo site que veiculou as matérias supramencionadas:

[...] É uma brutalidade sem tamanho. Muita maldade dessa assassina. Matou uma menina nova, e uma criança inocente. São dois crimes bárbaros. Merece acabar a vida na cadeia. Assim pagará pelo seu erro.

[...] "Suspeita" de matar jovem grávida e tirar feto do útero confirma crime". Ela confessou ela não é mais suspeita.

[...] Ela assassinou friamente a mãe e o filho que ainda não tinha nascido. Agora ninguém pode tocar a mấo nela. Ela tem a proteção da polícia da Justiça é de e Coisa e Tal. No Brasil, é assim se você quiser ter a justiça a seu favor seja bandido ou assassino." 
[...] estou arrepiado com esta notícia. porque? preservar a vida de pessoas táo sujas, táo ruins, que já superou a maldade humana, se algumas pessoas que está nesta terra não merece estar vivas, esta mulher com certeza é [sic.] uma delas, se ela fez isso mesmo (OLIVEIRA; FIGUEIREDO, 2016, grifos nossos).

Tais comentários são uma pequena parcela entre todos os que se encontram na reportagem em questáo, denotando à acusada a culpa, mesmo que esta, até o presente momento, não tenha ido a julgamento do tribunal do júri, demonstrando que desejam a condenação da acusada, mesmo que antes da apreciação das provas em plenário.

Com base nesses dois casos concretos, verificou-se que aos jurados é imposto um árduo trabalho de representar a sociedade no Poder Judiciário e que, em virtude das citadas notícias e matérias, vem reiteradamente sendo utilizado de forma incorreta, desrespeitando os preceitos fundamentais, entre eles, a dignidade da pessoa humana e da presunção de inocência do(a) acusado(a).

\section{Possibilidades a serem analisadas e suas consequências}

A atuação nos meios de comunicação implica diretamente a aplicação dos objetivos tutelados pelo tribunal do júri, que consistem em evitar o arbitramento estatal no tocante aos crimes dolosos contra a vida

A liberdade de imprensa, como visto anteriormente, não é plena e absoluta. Apesar de a Constituinte de 1988 dispor, no art. 220, sobre o irrestrito Direito à manifestação e à informação, cabe apontar que a supracitada norma ainda pontua uma orientaçấo principiológica em seu art. 221 e seguintes. Deste modo, ao se informar e manifestar, as emissoras de rádio e televisão deverão atender concretamente aos desejos constituintes, pois diversas vezes influenciam o cidadão, o qual, de igual modo, exercita os direitos constitucionais acima apontados. Segundo as palavras de Sarlet (2014, p. 198), não se deve "[...] falar em direitos fundamentais absolutos ou conferidos ao seu titular de maneira ilimitada [...]". Contudo, o direito de imprensa deve ser preservado, ainda que esta reiteradamente cruze as limitaçóes pré-estabelecidas.

O ideal é que haja um corpo de jurados imparcial e apto a julgar segundo suas convicçôes, após a análise de provas com observação do contraditório e ampla defesa, e não reproduzir o que foi visto nas capas de revistas e matérias de telejornais. Contudo, até se alcançarem a responsabilidade de que o pré-julgamento é um vício a ser sanado no decorrer do processo e a acepção de que a mídia 
produz efeitos, ainda que de forma indireta, deve-se buscar a adoção de medidas, institutos consistentes e concretos para garantir a integridade do réu.

Neste caso, o art. 427 do Código de Processo Penal dispóe sobre desaforamento, que é umas das maneiras de possibilitar um julgamento justo ao réu, consistindo em remeter o julgamento pelo plenário do júri para a comarca mais próxima, quando estão presentes os requisitos ali mencionados, entre eles, quando houver dúvida sobre a imparcialidade dos jurados:

Art. 427. Se o interesse da ordem pública o reclamar ou houver dúvida sobre a imparcialidade do júri ou a segurança pessoal do acusado, o Tribunal, a requerimento do Ministério Público, do assistente, do querelante ou do acusado ou mediante representação do juiz competente, poderá determinar o desaforamento do julgamento para outra comarca da mesma regiáo, onde não existam aqueles motivos, preferindo-se as mais próximas.

Todavia, nos casos de repercussão nacional, seria quase impossível a resolução do impasse com a mídia, já que os cidadáos das comarcas próximas estariam afetados por ela.

Por outro lado, há de se mencionar que, nos Estados Unidos, há uma série de medidas dispostas em lei que podem ser adotadas pelo juiz togado com o intuito de sanar qualquer vício no julgamento. Entre essas medidas, está prevista a possibilidade de renúncia ao júri por escolha do acusado.

Já no Brasil, é mais que sabido que a Constituição Federal de 1988 reconhece o tribunal do júri, constituindo este como uma garantia fundamental, ainda que maculado por fatores extrajudiciais, entre eles, a mídia. Desse modo, a renúncia ao tribunal do júri pode se tornar uma opção para o réu, não sendo uma causa inédita em ordenamentos jurídicos de outros países.

Sabe-se que nossa Lei Superior nada trata sobre a renúncia ao exercício do direito fundamental citado (FREITAS, 2016), sendo majoritário o posicionamento de que, por serem direitos inatos, não podem ser renunciados pelo sujeito desse direito. $\mathrm{O}$ que se admite seria seu não exercício, mas não sua renunciabilidade.

Novais (1996 apud FARIAS; TEIXEIRA, 2016, p. 306), de modo diverso, pontua:

A renúncia é também uma forma de exercício do direito fundamental, dado que, por um lado, a realizaçâo de um direito fundamental inclui, em alguma medida, a possibilidade de se dispor dele, inclusive o sentido de sua limitação, desde que esta 


\begin{abstract}
seja uma expressáo genuína do direito de auto-determinaçáa e livre desenvolvimento da personalidade individual, e porque, por outro lado, através da renúncia o indivíduo prossegue a realização de fins e interesses próprios que ele considere, no caso concreto, mais relevantes que os fins realizáveis através de um exercício positivo do direito.
\end{abstract}

Com base nas palavras do autor derradeiro e nos fatores midiáticos que influenciam nas decisôes jurídicas, a renúncia ao tribunal do júri é uma situação plausível, visto que somente necessita de regulamentaçáo sobre o tema. Isso porque, considerando que o réu possa, contra sua vontade, ser julgado por cidadáos que não estáo em mesma situação que a sua e que, muitas vezes. se entregam às pressôes midiáticas, torna-se inviável o uso desse direito fundamental.

\title{
Consideraçóes finais
}

Com esta pesquisa, buscou-se analisar, a partir de preceitos elencados no decorrer do trabalho, a influência da mídia nas decisóes proferidas pelo tribunal do júri, tendo o presente estudo realizado abordagem sobre o posicionamento dos jurados mediante a prática de delitos em grande repercussão.

Isso porque os meios de comunicação, ao exercerem seus papéis constitucionais, ultrapassam de forma violadora o objetivo de informar o cidadão sobre as notícias recorrentes, passando a induzir sobre este determinadas influências de pensamento, por intermédio do sensacionalismo, estando tais notícias diariamente à disposição da população. Cabe mencionar que as citadas induçôes são feitas de forma clara e sem receio algum, já que os meios midiáticos usam de suas prerrogativas constitucionais de liberdade de expressão/informação para abordar assuntos que trazem em seu âmago preconceitos enraizados desde a época de formação de nosso país, com o único intento de auferir lucro, gerado pelos índices de audiência.

Um dos principais focos estudados no presente artigo foi o dos conflitos evidenciados que o abuso na liberdade de informação gera na presunção de inocência do acusado, pois há recorrente juízo de valor exercido por uma pessoa que ainda não foi condenada em definitivo. A liberdade de comunicação deve ser orientada por meio de medidas públicas, assim como aqueles que, por anos, tiveram sentimento de vingança e por justiça de modo inconsciente, buscando satisfazer as garantias constitucionais, evitando, assim, que o sentimento pessoal gradualmente induzido anteriormente influa nas decisóes em plenário. 
Entre as medidas públicas, verificou-se a existência do instituto do desaforamento, já regulamentado pelo Código de Processo Penal e utilizado nos casos em que há dúvida sobre a imparcialidade dos jurados. Embora o citado instrumento, com redação dada pela Lei n. 11.689, de 2008, tenha muito a desenvolver, demonstra-se desde já ineficaz para assegurar um julgamento justo ao réu, já que não há barreiras para a propagação de informação, de modo que a comarca a que seja destinada a realização do plenário também tenha sido atingida.

Assim, encarando a realidade atual do júri, com reiteradas influências exteriores sobre os jurados, muitas delas difundidas pela própria mídia, verifica-se ser quase impossível a asseguração da dignidade da pessoa humana ao acusado, surgindo, ainda que de maneira íntima, o desejo de renúncia ao tribunal do júri, sendo julgado por juízes de Direito e não de fato, garantindo, assim, de maneira efetiva, ou pelo menos de forma mais ampla, os direitos fundamentais e sociais, a serem protegidos pelas autoridades judiciais.

\section{Referências}

BARBOSA, R. O júri e a independência da magistratura. Rio de Janeiro: MEC, 1897. p. 148. (Obras Completas de Rui Barbosa, v. XXIII, tomo III). Disponível em: <http://www.stf.jus.br/bibliotecadigital/ruibarbosa/18428/pdf/18428.pdf>. Acesso em: 18 maio. 2018.

BORDIEU, P. Sobre a televisão. Rio de Janeiro: Zahar, 1997.

BRASIL. Código de Processo Penal. Decreto-Lei n. 3.689, de 3 de outubro de 1941. Código de Processo Penal. Disponível em: <http://www.planalto.gov.br/ ccivil_03/decreto-lei/Del3689.htm>. Acesso em: 18 mar. 2018.

BRASIL. Constituiçẫo (1824). Constituição Politica do Império do Brazil. Rio de Janeiro, 1824. Constituição Política do Império do Brasil, elaborada por um Conselho de Estado e outorgada pelo Imperador D. Pedro I, em 25.03.1824. Disponível em: <www.planalto.gov.br/ccivil_03/constituicao/constituicao24.htm>. Acesso em: 21 abr. 2018.

BRASIL. Constituição (1988). Constituição da República Federativa do Brasil. 15. ed. atual. e ampl. - São Paulo: Saraiva Educação, 2018.

BRASIL. Lei n. 11.689, de 9 de junho de 2008. Altera dispositivos do Decreto-Lei n. 3.689, de 3 de outubro de 1941 - Código de Processo Penal, relativos ao Tribunal do Júri, e dá outras providências. Disponível em: <http://www.planalto.gov. br/ccivil_03/_Ato2007-2010/2008/Lei/L11689.htm>. Acesso em: 24 jul. 2019. 
CAPEZ, F. Curso de Processo Penal. 16. ed. São Paulo: Saraiva, 2009.

FARIAS, C. M.; TEIXEIRA, J. P. A. Renúncia a direitos fundamentais: modalidades e efeitos a partir da teoria constitucional contemporânea. Revista Pensamento Jurídico, São Paulo, v. 9, n. 1, p. 290-139, 2016.

FREITAS, P. C. Criminologia midiática e tribunal do júri: a influência da mídia e da opinião pública na decisão dos jurados. Rio de Janeiro: Lumen Juris, 2016.

GARLAND, D. A cultura do controle: crime e ordem social na sociedade contemporânea. Rio de Janeiro: Revan, 2008. p. 338.

LEHFELD, L. S.; LÉPORE, P. E; FERREIRA, O. A. V. A. Monografia jurídica: guia prático para elaboração do trabalho científico e orientação metodológica. 2 ed. rev., atual. e ampl. Rio de Janeiro: Forense; São Paulo: Método, 2015.

LEITE, B. E. A influência da mídia no princípio da presunção de inocência no tribunal do júri. Tenente Portela: PUC-RS, 2011. Disponível em: <http://www3.pucrs. br/pucrs/files/uni/poa/direito/graduacao/tcc/tcc2/trabalhos2011_1/bruna_leite. pdf>. Acesso em: 24 jul. 2019.

LIMA, R. B. Manual de processo penal. v. I. 5. ed. rev. ampl. e atual. Salvador: JusPodivm, 2017.

MELLO, C. G. Mídia e crime: liberdade de informação jornalística e presunção de inocência. Revista de Direito Público, Londrina, v. 5, n. 2, p. 106-122, ago. 2010. Disponível em: <http://www.uel.br/revistas/uel/index.php/direitopub/article/view/7381/6511>. Acesso em: 10 abr. 2018.

MENDES, G. F.; BRANCO, P. G. G. Curso de direito constitucional. 11. ed. São Paulo: Saraiva, 2016. (Série IDP).

OLIVEIRA, A.; FIGUEIREDO, T. Mulher fingiu gestação e matou jovem grávida para ficar com bebê, diz polícia. G1, 14 out. 2016. Disponível em: <http:// g1.globo.com/sp/ribeirao-preto-franca/noticia/2016/10/mulher-fingiu-gestacao-e-matou-jovem-gravida-para-ficar-com-bebe-diz-policia.html>. Acesso em: 22 jul. 2019.

PORTO, H. A. M. Júri: procedimentos e aspectos do julgamento - questionários. São Paulo: Saraiva, 2007.

PRATES, F. C.; TAVARES, N. F. A. A influência da mídia nas decisões do conselho de sentença. Revista Direito e Justiça. Porto Alegre, v. 34, n. 2, p. 33-39, jul./ dez. 2008. 
ROCHA, C. Daniella Perez: 20 anos do assassinato que mudou a lei. O Globo. Rio de Janeiro, dez. 2012. Disponível em: <https://oglobo.globo.com/rio/daniella-perez-20-anos-do-assassinato-que-mudou-lei-7125130>. Acesso em: 15 abr. 2018.

SARLET, I. W. Dignidade da pessoa humana e direitos fundamentais na Constituição de 1988. Porto Alegre: Livraria do Advogado, 2012.

SARLET, I. W. Notas introdutórias ao sistema constitucional de direitos e deveres fundamentais. In: CANOTILHO, J. J. G.; MENDES, G. F.; SARLET, I. W. (Coords.). Comentários à Constituição do Brasil. São Paulo: Saraiva-Almedina, 2014. p. 185-213.

TESTEMUNHA NEGA que acusada de matar grávida e tirar feto do útero para ficar com bebê eram amigas. G1, 9 jun. 2017. Disponível em: <https://g1.globo. $\mathrm{com} / \mathrm{sp} /$ ribeirao-preto-franca/noticia/testemunha-nega-que-acusada-de-matar-gravida-e-tirar-feto-do-utero-para-ficar-com-bebe-eram-amigas.ghtml>. Acesso em: 26 maio 2018.

ZAFFARONI, E. R. A palavra dos mortos: conferências de criminologia cautelar. São Paulo: Saraiva, 2012. 